\title{
Investigating the effects of technical trainings applied 10-12 age male tennis players on their stroke performances
}

\author{
Gürhan Suna ${ }^{1}$ \\ Mahmut Alp ${ }^{2}$ \\ Erkan Çetinkaya ${ }^{3}$
}

\begin{abstract}
The aim of this study is to investigate the effects of technical trainings applied 10-12 age tennis players on their stroke performances. 16 male tennis players joined to the study who are in Isparta and match in tournaments as individuals regularly. These were detected from players that mean of age was 10,62, \pm 80 years, mean of height was $144,06 \pm 8,28 \mathrm{~cm}$ and mean of weight was $38,75 \pm 9,04$ $\mathrm{kg}$. Trainings were applied to the players as technical 3 days a week and as condition 1 day a week. ITN test (International Tennis Number) were applied to test the stroke performances. Datas were compared by using "Paired t Test" at SPSS 18.0 statistic programme. Differences were found to be statistically significant at result of comparing stroke performances' pre-posttests $(p<0,05)$. This study shows the regular technical and conditional trainings' positive effects on performance and provides recommendations to trainers and sport scientists about planning, programming a training and defining performance criteria.
\end{abstract}

Keywords: Tennis, Training, Performance.

\section{Introduction}

Nowadays, tennis is a sport branch that has great potential worldwide as a performance sports attracting individuals from every category. In tennis and other sports branches, selection of talented athletes can be done by ensuring participation in sports at an early age. Ensuing the emergence of successful tennis players in the international arena can be achieved by only having children playing tennis at their early ages (Çalsskan, 2014). This much interest in tennis around the globe has brought different perspectives. On the one hand, it is a popular recreational activity done by people in the elite level; on the other hand, it has become a competitive sport for providing a significant amount of revenue. Regular trainings should be started at early ages in order to have a continuous development and keep the performance of the players at high levels in tennis game (Unierzyski, 1995).

Motor skills, which mean the use of force required to perform an athletic move, can be acquired by use, experience and training at early ages (Mengütay, 1999). Development of these sports skills can be achieved with the help of trainings (Kermen, 1992). In parallel, tennis stroke techniques are also developed with the help of training activities. The physical fitness of professional tennis players and tennis technical trainings are based on a solid foundation established at a young age. These players should devote a large part of their trainings to physical fitness and special technical work (Okudur, 2010).

\footnotetext{
${ }^{1}$ Ph.D. Student, Sakarya University, Institute of Educational Sciences, Department of Physical Education and Sports, gurhansuna@windowslive.com

2 Ph.D. Student, Celal Bayar University, Institute of Health Sciences, Department of Coaching Training/Sport Sciences, mahmut.alp@windowslive.com

${ }^{3}$ Assist. Prof. Dr., Adnan Menderes University, Physical Education and Sports College, erkcetinkaya09@hotmail.com
} 
Suna, G., Alp, M., \& Çetinkaya, E. (2016). Investigating the effects of technical trainings applied 10-12 age male tennis players on their stroke performances. Journal of Human Sciences, 13(3), 4980-4985. doi:10.14687/jhs.v13i3.4019

In light of these informations obtained from the literature, the aim of this study is investigating the impact of technical trainings performed by 10-12 year old male tennis players on their stroke performance.

\section{Method}

Participants: A total of 16 tennis players competing in tennis tournaments individually participated in the study. The mean age of the athletes is recorded as $10.62 \pm 0.80$ years, the average height is $144.06 \pm 8.28 \mathrm{~cm}$ and the average body weight was recorded as $38.75 \pm 9.04 \mathrm{~kg}$, respectively.

"Informed Consent Form" was obtained from parents of the students participating in the study; they were informed about that personal information and findings obtained during the study will be kept confidential.

Procedures: Athletes were subjected to technical training 3 times a week and fitness training once a week. The start of preparation period and the end of 12 weeks-period were taken as basis of pretest and post-test measurement times. Trainings were continued until the summer season. All trainings and tests of the study group were conducted in Tennis Center building of Süleyman Demirel University.

\section{Training Model:}

Table 1. Training model applied to the study group

\begin{tabular}{|c|c|c|c|c|}
\hline & Monday & Tuesday & Thursday & Saturday \\
\hline $\begin{array}{l}1^{\text {st }}, 2^{\text {nd }} \text { and } \\
3^{\text {rd }} \text { Weeks }\end{array}$ & $\begin{array}{l}\text {-Warm-up for } 20 \text { min. } \\
\text {-Technical developers } \\
\text { drill workout for } 60 \\
\text { min. } \\
\text { - Recovery for } 10 \mathrm{~min} . \\
\text { (low tempo running) }\end{array}$ & $\begin{array}{l}\text {-Warm-up for } 20 \text { min. } \\
\text {-Agility and Athletic workouts } \\
\text { for } 30 \text { min. } \\
\text { - Cat ladder (single foot right- } \\
\text { left both feet, passing exterior } \\
\text { to interior without stepping } \\
\text { on the ladder) } 3 \times 2 \text { sets, } \\
-5 \text { min. rest between sets } \\
\text { - Recovery for } 10 \text { min. }\end{array}$ & $\begin{array}{l}\text {-Warm-up for } 20 \text { min. } \\
\text {-Technical developers } \\
\text { drill workout for } 40 \\
\text { min. } \\
\text { - Recovery for } 5 \mathrm{~min} \text {. }\end{array}$ & $\begin{array}{l}\text {-Warm-up for } 20 \mathrm{~min} \text {. } \\
\text {-Playing with football } \\
\text { one to one and two to } \\
\text { two on the mini court } \\
\text { and Baseline for } 60 \mathrm{~min} \text {. } \\
\text { - Recovery for } 5 \mathrm{~min} \text {. }\end{array}$ \\
\hline $\begin{array}{l}4^{\text {th }}, 5^{\text {th }} \text { and } \\
6^{\text {th }} \text { Weeks }\end{array}$ & $\begin{array}{l}\text {-Warm-up for } 20 \text { min. } \\
\text { - Technical stroke drill } \\
\text { trainings for } 40 \text { min. } \\
\text { (Forehand- Backhand- } \\
\text { Serve) } \\
\text { - Rally workout for } 20 \\
\text { min. on the Baseline } \\
\text { - Recovery for } 10 \text { min. }\end{array}$ & $\begin{array}{l}\text {-Warm-up for } 20 \text { min. } \\
\text {-Agility and Athletic workouts } \\
\text { for } 30 \text { min. } \\
\text { - Moving out trainings } 2 \times 3 \\
\text { sets } \\
-5 \text { min. rest between sets } \\
\text { - Skipping rope } 3 \times 100 \text { times } \\
-5 \text { min. rest between sets } \\
\text { - Recovery for } 10 \text { min. }\end{array}$ & $\begin{array}{l}\text {-Warm-up for } 20 \text { min. } \\
\text {-Technical stroke drill } \\
\text { trainings for } 40 \text { min. } \\
\text { (Forehand- Backhand- } \\
\text { Serve) } \\
\text { - Rally workout for } 20 \\
\text { min. on the Baseline } \\
\text { - Recovery for } 10 \text { min. }\end{array}$ & $\begin{array}{l}\text {-Warm-up for } 20 \text { min. } \\
\text {-Technical stroke drill } \\
\text { trainings for } 40 \text { min. } \\
\text { (Forehand- Backhand- } \\
\text { Serve) } \\
\text { - Rally workout for } 20 \\
\text { min. on the Baseline } \\
\text { - Recovery for } 10 \text { min. }\end{array}$ \\
\hline $\begin{array}{l}7^{\text {th }}, 8^{\text {th }} \text { and } \\
9^{\text {th }} \text { Weeks }\end{array}$ & $\begin{array}{l}\text {-Warm-up for } 20 \text { min. } \\
\text {-Technical stroke drill } \\
\text { trainings for } 40 \mathrm{~min} \text {. } \\
\text { (Forehand- Backhand- } \\
\text { Serve) } \\
\text { - Rally workout for } 20 \\
\text { min. on the Baseline } \\
\text { - Recovery for } 10 \text { min. }\end{array}$ & $\begin{array}{l}\text {-Warm-up for } 20 \text { min. } \\
\text {-Agility and Athletic workouts } \\
\text { for } 30 \text { min. } \\
\text { - Stairs training ( } 50 \text { steps) } 3 \times 3 \\
\text { sets } \\
-6 \text { min. rest between sets } \\
\text {-Lactic stretching ( forehand- } \\
\text { backhand) } 4 \times 20 \\
-5 \text { min. rest between sets } \\
\text { - Recovery for } 10 \text { min. }\end{array}$ & $\begin{array}{l}\text {-Warm-up for } 20 \text { min. } \\
\text {-Rally workout for } 15 \\
\text { min. on the mini court } \\
\text {-Football one to one } \\
\text { and two by two for } 50 \\
\text { min. } \\
\text {-Cooling off for } 10 \\
\text { min. }\end{array}$ & $\begin{array}{l}\text {-Warm-up for } 20 \text { min. } \\
\text {-Technical stroke } \\
\text { trainings for } 40 \text { min. } \\
\text { (Forehand-Backhand- } \\
\text { Vole-Slam Dunk) } \\
\text { - Rally workout for } 20 \\
\text { min. on the Baseline } \\
\text { - Recovery for } 10 \text { min. }\end{array}$ \\
\hline
\end{tabular}


Suna, G., Alp, M., \& Çetinkaya, E. (2016). Investigating the effects of technical trainings applied 10-12 age male tennis players on their stroke performances. Journal of Human Sciences, 13(3), 4980-4985. doi:10.14687/jhs.v13i3.4019

\begin{tabular}{|c|c|c|c|c|}
\hline $\begin{array}{l}10^{\text {th }}, 11^{\text {th }} \\
\text { and } 12^{\text {th }} \\
\text { Weeks }\end{array}$ & $\begin{array}{l}\text {-Warm-up for } 20 \text { min. } \\
\text { - Rally workout for } 15 \\
\text { min. on the mini court } \\
\text { - Rally training one to } \\
\text { one and two by two for } \\
20 \text { min. on the Baseline } \\
\text { - } 30 \text { min. game } \\
\text {-Cooling off for } 10 \\
\text { min. }\end{array}$ & $\begin{array}{l}\text {-Warm-up for } 20 \text { min. } \\
\text {-Agility and Athletic workouts } \\
\text { for } 30 \text { min. } \\
\text { - Cat ladder (single foot right- } \\
\text { left both feet, passing exterior } \\
\text { to interior without stepping } \\
\text { on the ladder) } 2 \times 20 \text { times, } \\
-6 \text { min. rest between sets } \\
-6 \text { min. rest between sets } \\
\text { - Recovery for } 10 \text { min. }\end{array}$ & $\begin{array}{l}\text {-Warm-up for } 15 \text { min. } \\
\text { - Playing football for } 15 \\
\text { min. on the mini court } \\
\text { - } 50 \text { min. game } \\
\text {-Cooling off for } 10 \\
\text { min. }\end{array}$ & $\begin{array}{l}\text {-Warm-up for } 20 \text { min. } \\
\text { - Rally workout for } 15 \\
\text { min. on the mini court } \\
\text { - Rally workout one to } \\
\text { one and two by two for } \\
50 \text { min. on the Baseline } \\
\text {-Cooling off for } 10 \text { min. }\end{array}$ \\
\hline
\end{tabular}

\section{Technical Stroke Test:}

\section{ITN Test (International Tennis Number)}

This is an important test developed and applied by International Tennis Federation (ITF) in order to identify initial and development level of athletes in tennis sports.

General Evaluation Rules

Players should be warmed and well prepared before the game. Each player is given 4 tries before each test section (forehand and backhand, volley, serve). The player has the right to refuse ball fed before the stroke. If there is a physical contact with the ball, then the stroke is taken into evaluation. High scores are considered when ball is dropped on the line. The authority of evaluator is valid during evaluations and the last decision is made by the evaluator. All scores are recorded after each stroke and at the end of each section. Test evaluation form is signed by the player and evaluator after evaluations. One copy of the form is given to the player.

\section{Test Procedure}

- Depth measurements including strength measurements for ground strokes (A total of 10 strokes including 1 forehand, 1 backhand, respectively)

- Accuracy measurements including strength measurements for ground strokes (A total of 6 strokes; 1 forehand parallel, 1 backhand parallel and 6 strokes; 1 forehand cross, 1 backhand cross, respectively)

- Depth measurements including strength measurements for volley strokes (A total of 8 strokes, including 1 forehand, 1 backhand, respectively)

- Serve including strength measurement (A total of 12 serves, 3 serves to each target area)

- Mobility (agility measurement) test

\section{Ball Feeder Instructions}

During testing period, it is necessary to make sure that the ball feeder and the test subject (player) should be in the right place. The ball feeder should provide simple and stable ball throws to all players. The ball feeder should wait until the player is ready to receive the ball. The player and ball feeder has the right to refuse the ball before the stroke. If there is a physical contact with the ball, then the stroke is taken into evaluation.

Maximum Scores

- Depth Tests on the Ground Strokes.

90 Points

- Accuracy and Strength Test on the Ground Strokes.

84 Points

- Depth Tests on the Volley Strokes.

72 Points

- Test of Serve Strokes.

108 Points

- Agility Test.

76 Points

The highest score that can be achieved

430 Points 
Suna, G., Alp, M., \& Çetinkaya, E. (2016). Investigating the effects of technical trainings applied 10-12 age male tennis players on their stroke performances. Journal of Human Sciences, 13(3), 4980-4985. doi:10.14687/jhs.v13i3.4019

\section{Test Evaluation Scoring}

- 0 point(s): If the first contact of the ball is outside of the line of singles

- 1 point(s): If the first contact of the ball is within somewhere in serve boxes

- 2 point(s): If the ball falls back to the first court in the divided area

- 3 point(s): If the ball falls back to the second court in the divided area

- 4 point(s): If the ball falls back to the last court in the divided area

\section{$\underline{\text { Strength Scores }}$}

- Strength Area $=1$ Bonus Point - If the second bouncing of the ball is anywhere between baseline and strength line after the first bouncing in anywhere in the singles court, then the player receives an additional 1 point.

- Strength Area $=$ Double Points - If the second bouncing of the ball is anywhere behind strength line after the first bouncing in anywhere in the singles court, then the player receives double points received from the first bouncing (www.internationaltennisnumber.com).

Statistical Analysis: Statistical analysis of the data was performed on SPSS 18.0 (Statistical Package for Social Sciences) program. "Shapiro-Wilk Test" was used for normality and "Paired t test" was used for comparison of ITN values. Results were evaluated according to significance level of "p $<0,05 "$.

\section{Findings}

Table 2. Result of Normality Test

\begin{tabular}{|c|c|c|c|c|c|}
\hline$(n=16)$ & & & $\bar{X}$ & SS & $\mathrm{p}$ \\
\hline \multirow{2}{*}{$\begin{array}{l}\text { ITN } \\
\text { (points) }\end{array}$} & Test & Pre Test & 122,25 & 23,73 & ,081 \\
\hline & & Post Test & 143,68 & 24,82 & 177 \\
\hline
\end{tabular}

Considering the data given in Table 2, distribution of ITN pre and posttest values were found statistically normal.

Table 3. The Comparison of Pre and Post ITN Test Values

\begin{tabular}{|c|c|c|c|c|c|}
\hline$(n=16)$ & & $\bar{X}$ & SS & $\mathbf{t}$ & $\mathrm{p}$ \\
\hline \multirow{2}{*}{$\begin{array}{l}\text { ITN Test } \\
\text { (points) }\end{array}$} & Pre Test & 122,25 & 23,73 & \multirow{2}{*}{$-25,03$} & \multirow{2}{*}{,000 } \\
\hline & Post Test & 143,68 & 24,82 & & \\
\hline
\end{tabular}

Considering the data given in Table 3 , a significant difference was found between ITN score applied on athletes and average scores of the posttest $(p<0,05)$. 

players on their stroke performances. Journal of Human Sciences, 13(3), 4980-4985. doi:10.14687/jhs.v13i3.4019

\section{Discussion}

In research, which was conducted to determine the effect of technical trainings on stroke performances of 10-12 years old male tennis players, technical trainings for 3 days and fitness trainings for 1 day were applied to the athletes. The beginning of preparation period and end of a 12 weeks period were determined to be the measurement dates of pretests and posttests.

As a result of 12-week training, the average ITN pre-test scores of the participants to study was found as 147,21 $\pm 36,06$ points, whereas their post-test scores was found to be 160,51 $\pm 37,38$ points. Accordingly, a significant improvement was observed in the tennis skills of the participants.

In the research of Suna (2013), which was aiming to determine the effect of aerobic, anaerobic, technical and combined trainings on the performance of tennis players, the average ITN pretest score was found as 124,3 $\pm 22,6$ points; and the average post-test score was found as 193,5 \pm 20,5 points. According to the result of the statistical comparisons applied on findings obtained by the researcher, there is a significant difference. Suna stated the results of performance increment that uniting the combine trainings which develop the motoric skills with technical trainings. The data obtained is consistent with our findings.

In the study of Özcan (2011), which was aiming to determine the effect of two different training methods on biomotoric and physiological characteristics in basic tennis technical education, the athletes were divided into two groups and tennis training was applied on one of the groups with inductive method and deductive method was applied on the other group. In the study, ITN test was used to determine improvements of tennis players as we did in our study. As a result of the study, significant difference was found between ITN pretest and posttest scores of tennis players received tennis training in both groups.

In a study conducted by Söyleyici (2011), which was aiming to determine the intensive 8-week strength and technical trainings on biomotoric and technical development of tennis players in the technical tennis trainings, the average ITN pre-test scores of players was found as $75 \pm 0,0$ points

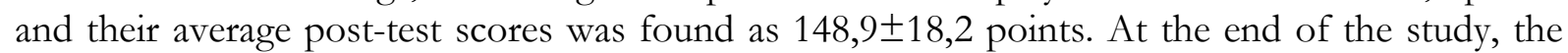
increase in ITN scores of the athletes was found to be statically significant. These results are consistent with our findings. In addition, result of this study supports our research findings.

Çalıskan (2014) aimed to determine the effects of strength and technical trainings applied to children on tennis skill development and some motoric features. As a result of ITN Test values, he found significant difference. He stated in the study as the same as Suna that applying motoric and technical trainings contemporaneously will affect the tennis skills positively.

Oppositely Ölçücü et. all (2010) aimed to evaluate conditional of coordinative factor affecting the acqusition of tennis skills of the youngs who have done one of the sports before related to the balls and who haven't done. They did not find differences in ITN Test values. They stated lack of development reason that the trainings period was not enough to develop both motoric and tennis skills.

\section{Conclusion}

According to the data obtained, positive improvements were observed in the stroke performance of 10-12 years old tennis players. In addition, it has been concluded that technical trainings have also positive impacts on tennis skills of children.

We believe that our study will make positive contribution to sportive performance of players as well as providing reference values for coaches applying technical trainings in tennis. Furthermore, we think that our study is important in terms of creating plans and programs of trainings based on results of stroke performance analysis.

We think that it is necessary to apply well-planned and programmed trainings in terms of conditional and coordinative characteristics in order to support skill learning and performance 
Suna, G., Alp, M., \& Çetinkaya, E. (2016). Investigating the effects of technical trainings applied 10-12 age male tennis players on their stroke performances. Journal of Human Sciences, 13(3), 4980-4985. doi:10.14687/jhs.v13i3.4019

developments in tennis. In future studies, the effect of conditional and coordinative characteristics on the stroke performance can be analyzed.

\section{References}

ÇALIŞKAN, İ.V. (2014). Investigating the Effects of Technique and Strength Training on 12-14 Age Tennis Players. M.Sc. Thesis, Unpublished. Isparta: Süleyman Demirel University.

KERMEN, O. (1992). Tennis Didactic and Methodology. Ph.D. Thesis, Published. İstanbul: Marmara University.

MENGÜTAY, S. (1999). Physical Education and Sport at Preschool and Primary School. Ankara Tutibay Publishing, pp.3-6.

OKUDUR, A. (2010). Investigation of tennis players age 12 in Balance and Agility Relations. M.Sc. Thesis, Unpublished. Konya: Selçuk University.

ÖLÇÜCÜ, B., CANİKLİ, A., AĞAOĞLU, Y. S., ERZURUMLUOĞLU, A. (2010). Evaluation Of Factors Affected On Improvements Of The Tennis Skills In Children 10-14 Years Old. Atabesbd; 12 (2) : 1-11.

ÖZCAN, S. (2011). Investigating the Effects of Two Different Methods in Tennis Technical Education on Technical Training, Biomotoric and Physiological Properties. M.Sc. Thesis, Ubpublished. Isparta: Suleyman Demirel University.

PUERTA. H., MAQUIRRIAIN, J., AQUILINO, G., CARDEY, M., GUILLONE, C., DIAZ, I., LENTINI, N., PAPINI, H. R. Body Composition Profile of Argentine Tennis Players. Access: [http: //www.stms.nl/april2002/artikel11.html]. Access Date: 09.12.2003.

SÖĞ̈̈T, M., MÜNİROĞLU, S. R., DELICEOĞLU. G. (2004). Investigating the Anthropometric and Somatotip Properties of Young Male Tennis Players in Different Categories. SPORMETRE Journal of Physical Education and Sports Science, Volume II, Issue 4.

SÖYLEYICI, Z. S. (2011). Investigating the Effects of 8-Week Intensive Force and Technical Training Program on Biomotoric and Technical Development. M.Sc. Thesis, Ubpublished. Isparta: Süleyman Demirel University.

SUNA, G. (2013). Investigating the Effects of Aerobic, Anaerobic, Technical Combined Trainings on Performance in Tennis Players. M.Sc. Thesis, Ubpublished. Isparta: Süleyman Demirel University.

UNIERZYSKI, P. (1995). Influence of Physical Fitness Specific to the Game of Tennis, Morphological and Psychological Factors on Performance Level in Tennis in Different Age Groups. Science and Racket Sports. London: E \& FN Spon; p: 61-68.

Official Web Site of International Tennis Federation 2013. From $<$ http://www.internationaltennisnumber.com> (Retrieved March 13, 2013)

YAVUZ, B. (1990). Investigating the Relationship Between Girls' and Boys' 12-14 Morphological Traits and Motoric Performance of Tennis Players. M.Sc. Thesis, Published. İstanbul: Marmara University. 